\title{
SEGMENTATION OF CONSUMERS \\ IN THE CONTEXT OF THEIR SPACE \\ BEHAVIOUR: CASE STUDY OF BRATISLAVA
}

\section{Marta Grossmanová, Pavol Kita, Marta Žambochová*}

\begin{abstract}
The paper analyses the evolution of the retail network of the capital city of Slovakia Bratislava affecting buying behaviour and lifestyle of its consumers. From the marketing point of view, it characterizes the space behaviour of the consumers and presents the behaviour of consumers living in single districts of Bratislava. It shows, on the one hand, how the importance of consumer behaviour rises in the declining economic prosperity during last years, while on the other hand, the concentration in retail declines the chances for success of small independent food retail stores during last recent years. The authors used different methods, e.g. GIS, cluster analysis, for testing they asses the significance of market segments on the sample involving 11,389 respondents interviewed.
\end{abstract}

Keywords: space, retail network, consumer behaviour, segmentation of market JEL Classification: M31, C38

\section{Introduction}

Retail trade in many towns or regions is considered to be a branch ensuring its socioeconomic development. Besides necessary natural, cultural and historical preconditions together with material-technological basis of retail trade, development of a town or region is also determined by its transport accessibility. Good accessibility of a town contributes to its total attractiveness, which can result in a higher number of visitors (Thang, Tan, 2003). On the contrary, improper level of accessibility of a town may cause lower use of the retail trade potential, which is often reflected in a low level of turnover and selling space of point of sale. The aim of this paper is to analyse market segments of the consumers in the town Bratislava in the context of their space behaviour in order to increase the commercial attractiveness of its city districts.

\section{Theoretical and Methodological Bases for Work}

Study of space behaviour of the consumers offers an opportunity, both strategically and tactically. In this context the space interactions are a result of influence of many factors and show the mutual interdependence and functioning of different facts. In the case of

* Marta Grossmanová, University of Economics in Bratislava, Faculty of Applied Languages,

Department of English language (marta.grossmanova@euba.sk);

Pavol Kita, University of Economics in Bratislava, Trade Faculty, Marketing Department, Bratislava (pavol.kita@euba.sk);

Marta Žambochová, J. E. Purkyně University in Ústí nad Labem, of Social and Economic Studies, Department of Mathematics and Informatics (marta.zambochova@ujep.cz).

The paper presents the results of Research Project VEGA No. 1/0039/11 Geographical Information System as a Source of Strategic Innovation of Enterprise from the Point of View of Strengthening Its Competitiveness. 
retail trade the interactions are created mainly between the place of living of a customer and the place, which he/she visits most frequently (work, leisure), whilst the interactions are influenced by the very existence of the customer mobility. Accessibility is a key concept of actual territorial planning strategies as it represents a major driving force of socio-economic development of a region (Corodescu, 2014). Perception of accessibility of the point of sale by a customer creates the basic factor of the point of sale attractiveness (Boučková et al., 2007). Differentiation of attractiveness, possibilities and needs of inhabitants as well as reaching individual places of sales leads to the differences in competitiveness of retail points of sale. Customers make their choice according to the attraction or utility that they perceive from the facilities (Suárez-Vaga et al., 2011).

Within the analysis of locality as a precondition of deciding the location of the retail point of sale it is important to realize that this decision determines the distance to the customer, who must develop some effort to cover the distance, spend some time and have some costs for the possible transport (Šveda, Križan, 2012). The accessibility of point of sale expresses the possibility of reaching the offer of the point of sale in the so called acceptable time from the customer's point of view (Križan, Tolmáči, Lauko, 2008). It is a matter of reaching the distance. Time accessibility is given not only by the distance, but by the way of overcoming the distance and other factors as well. This results in the point of sale attractiveness which is proportional to its accessibility with regard to the level of specialization of the offer (Križan, et al., 2014). We can say that attractive location of the point of sale is related to three elements: customer, road network and retail network in a given town or village (Więckowski, Michniak, 2012). Their mutual interactions leading to the attractiveness of the point of sale are illustrated in the following Figure 1.

\section{Figure 1 | Interaction Customer-Point of Sale Road Network}

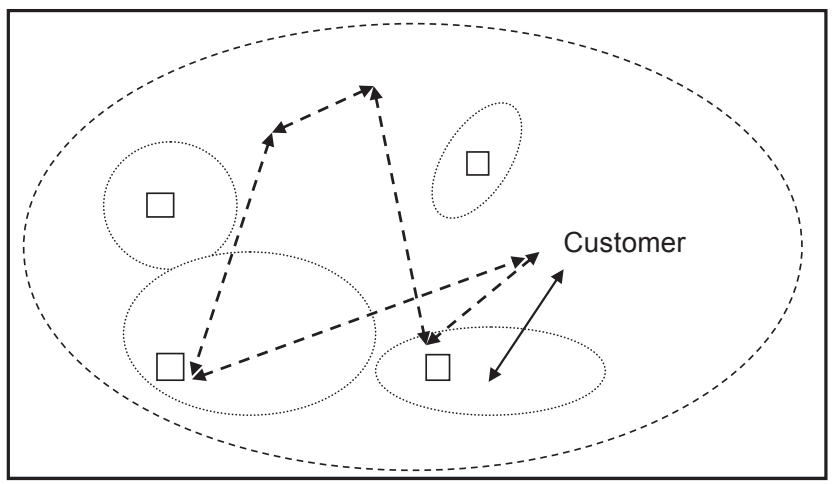

point of sale

radius of the point of sale

-.. road network

_ - movement of customer within the road network

$\leftrightarrow$ exchange of goods and money between customers and retailer

master plan 
Customer is attracted by the offer of the point of sale, which thus creates its radius and at the same time expresses the willingness of a customer to visit different points of sale distant from his place of living within the given road network of the town (Wooda, Reynolds, 2012). Figure 2 also shows the space behaviour of customer who decides visiting a point of sale independently and most often according to the offer of the point of sale, possibilities of transfer, level of disposable financial means and his/her motivation. Assuming certain customer preferences, the firms, whose natural objective is the maximization of the market share or profit, take their location decisions, influencing with their actions the results and strategies of their competitor (Suárez-Vega et al., 2014). Therefore, when locating a point of sale a distributer must judge its buying behaviour in evaluating the potential of the given sphere of interest (Kita, Konštiak, 2012).

Figure 2 | Starting Points of a Distributor when Localizing the Point of Sale in the City

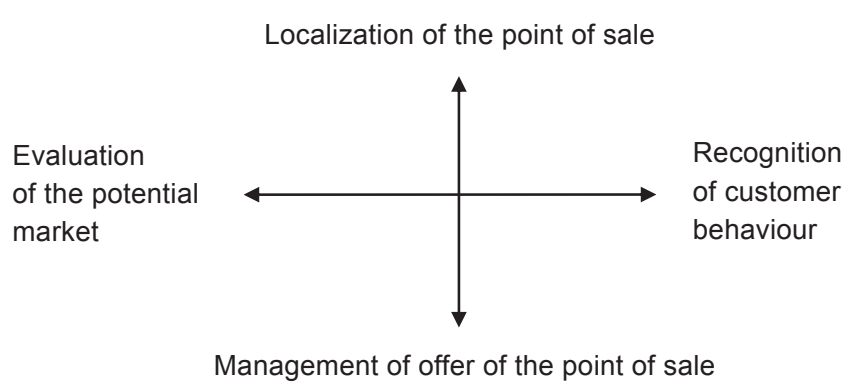

Source: Douard, J.-P.; Heitz, M. Le géomarketing. Paris: Dunod, 2004, p. 62.

A recent review of spatial interaction modelling can be found in papers, such as Roy and Thill (2004), Drezner (1994), Williams, Kim and Martin (1990).

\section{Empirical Elaboration of the Project}

The criteria for localization of the point of sale are related to the space dimension of geomarketing, which connects geography with the database of the data characterizing the purchasing behaviour of customers (Turhan, Akalin, Zehir, 2013), which makes it possible to personify the point of sale offer with regard to the localization conditions and in this way create an effective instrument of knowing the customer behaviour and develop an effective marketing of the point of sale.

The book (McDonald, 2000) or the article (Vojáček, 2011) deals with the investigation of preferences. The author (Vojáček, 2011) considers consumer preferences for one of the key concepts of the analysis of their behaviour. We realize, like the authors (Tsai, 2004), that only basic, general demographic variables are not sufficient for good segmentation. Therefore, we have extended these basic variables of variables informing about specific purchases, especially of the type of goods, purchase of characteristics (length, date of purchase, etc.), Satisfaction, or about the shortcomings of this purchase. The authors (Brida, 2014) used a similar analytical tools for segmentation, as we do, and cluster analysis and decision trees. For the purposes of segmentation of customers we have used two types of statistical methods of learning (Žambochová, 2012). It concerns supervised 
learning and unsupervised learning. As for the methods of unsupervised learning we have used a cluster analysis (Řezanková, 2009). Cluster analysis deals with the details of the data objects. It deals with dividing a set of objects into several beforehand unspecified clusters in such a way the objects inside individual clusters are of maximum similarity and objects of different clusters are of minimum similarity. Cluster analysis includes a great number of methods which are different from each other by deterring the similarities of objects, distances between clusters as well as the way of clustering (e.g. hierarchical and non-hierarchical.) The selection of a suitable method is made on the basis of the types of variables, which contains the set of data being processed (nominal, ordinal, quantitative variables), on the size of sets (i.e. the number of objects) or on the basis of the way of entering the data (e.g. source data in the primary form or matrix of similarities).

In our case we had at the disposal the methods implemented in the statistical system SPPS, specifically the hierarchical method, the k-means method and the two-step method. The $\mathrm{k}$-means method is determined for processing the numerical variables. So in our case it was not applicable, because our data also contained nominal variables. The hierarchical method was not suitable either as it is rather aimed at smaller sets of data and our data set consisted of the 11,389 objects. The processing would be very difficult. The more serious problem would be bad legibility of the result which is delivered in the form of a special tree structure, the so called dendogram. The method which best met our purposes was the two-step method.

In the case of supervised learning the deciding rules for classing the objects are made on the basis of training aggregate. The representative of this group method is decision trees. Decision trees (Žambochová, 2008) are the structures which recursively divide the set of the data researched according to specific decision criteria related to the explaining variables. The tree root represents the whole data set. The internal tree nods represent the subsets of the data set. The aim of construction is to create the most homogenous sets possible with regard to the variable being explained. So to create such a tree in the leaves of which there are included object sets, which if possible, are of the same value of the variable being explained. There are used two types of decision trees, specifically classification trees and regression trees. To create decision trees a large number of algorithms was created. The most used ones are CART, ID3, C4.5, AID, CHAID a QUEST.

In our case we had at the disposal the methods implemented in the statistical system SPSS and specifically CRT (CART), CHAID and QUEST. The trees created by means of algorithms CRT and QUEST are of binary type, which means they are always split into two parts. The trees constructed by means of algorithm CHAID are not binary and can be split to any number of parts. In all cases we constructed the decision trees by means of all these algorithms and then chose the best one.

\section{Results and Discussion}

The aim of the research carried out in 2011 in the territory of the capital of the Slovak Republic Bratislava was to create the space lay-out of the retail network (Figure 3) in the territory of the city using the knowledge of geomarketing and creation of database data about the retail network as a part of a geographic information system (GIS).

To get the answers a standardized questionnaire was used. It was completed by 11,389 respondents shopping in the retail establishments located in individual parts of the town Bratislava. The respondents had to comply with the conditions - to have a permanent or temporary residence in Bratislava and to be at least 18 years old. 
In the classification process we applied the following procedure. First we made a cluster analysis which divided the researched customers into mutually similar respondents according to their answers to the asked questions.

Figure 3 | Lay-Out of Retail Points of Sale in the Town Bratislava in 2011

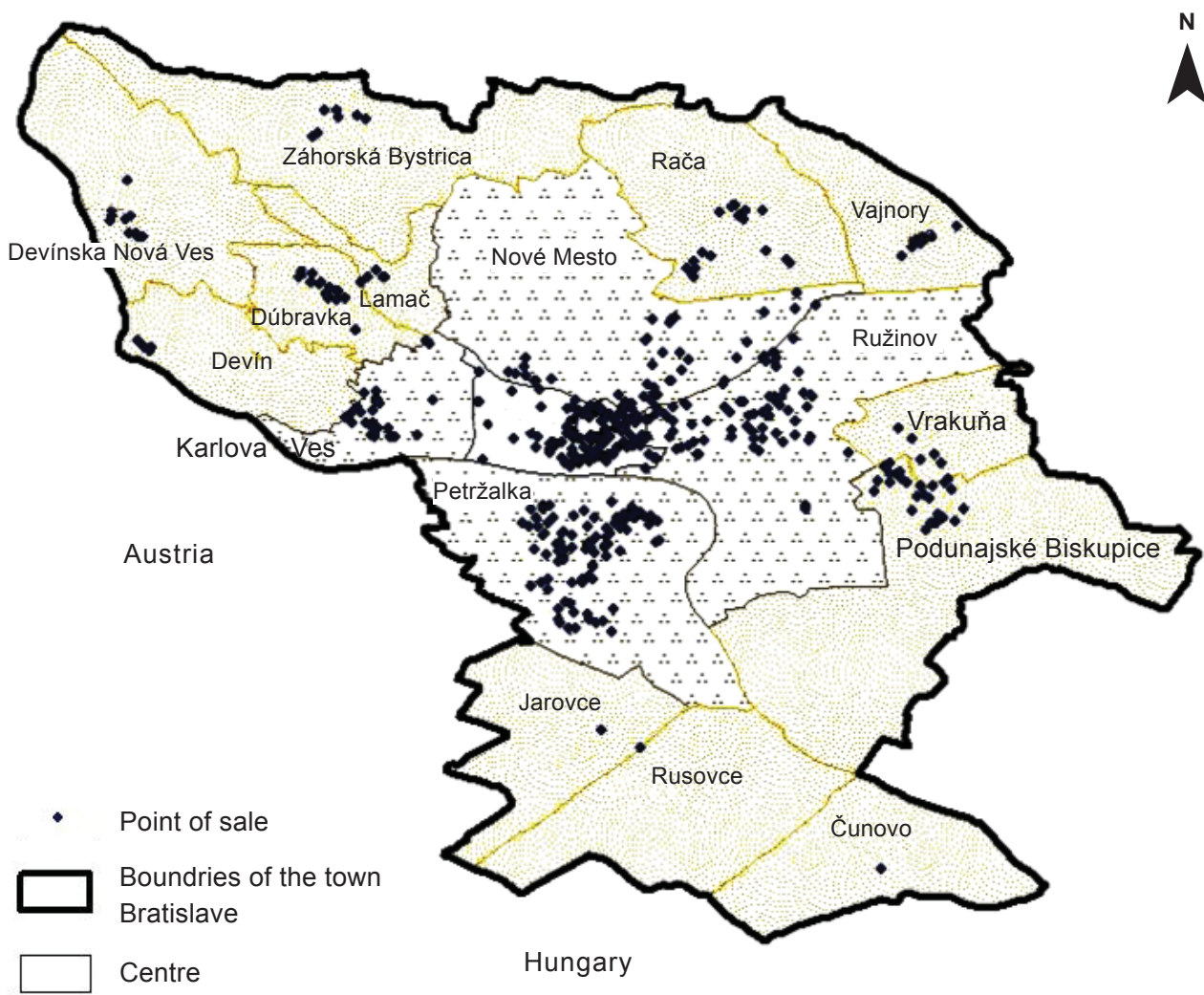

Inner town

Kilometers

Outer town

Source: The results of research within the Project VEGA No. 1/0039/11 Geographical Information System as a Source of Strategic Innovation of Enterprise from the Point of View of Strengthening Its Competitiveness.

The popularity of hypermarkets and supermarkets results from the fact that customers generally reason they prefer a car (an average of 4.87) as a means of transport to the point of sale and spend an average time of almost 14 minutes to get to the place of purchase. The customers, who marked the possibility not to prefer any of the given types of forms of points of sale claim that they do shopping at the time and the place when it suits them best. The Table 1 shows more exactly the answers of respondents to the question which way of transport to the food store they prefer. 


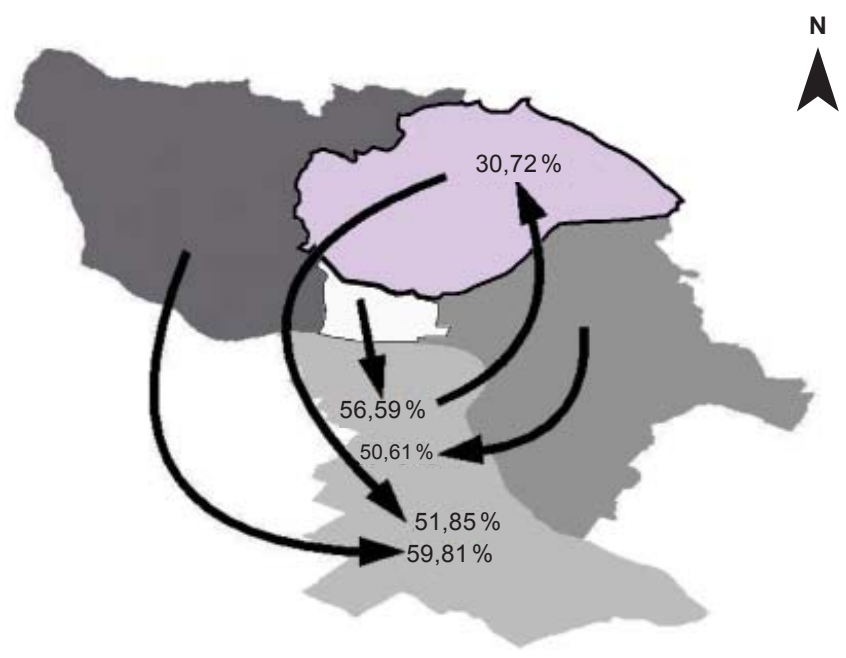

District

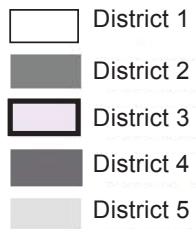

Source: The results of research within the Project VEGA No. 1/0039/11 Geographical Information System as a Source of Strategic Innovation of Enterprise from the Point of View of Strengthening Its Competitiveness.

Table 1 | Way of Transport of Customer to the Food Store

\begin{tabular}{|l|c|c|}
\hline Way of transport & $\begin{array}{c}\text { Relative share } \\
\text { of respondents }\end{array}$ & Average time \\
\hline by car & $40.82 \%$ & $13.50 \mathrm{~min}$. \\
\hline by public transportation & $30.28 \%$ & $16.36 \mathrm{~min}$. \\
\hline on foot + others & $28.42 \%$ & $13.50 \mathrm{~min}$. \\
\hline no response & $0.47 \%$ & $11.83 \mathrm{~min}$. \\
\hline Total & $100 \%$ & \\
\hline
\end{tabular}

Source: The results of research within the Project VEGA No. 1/0039/11 Geographical Information System as a Source of Strategic Innovation of Enterprise from the Point of View of Strengthening Its Competitiveness. The transfer of customers to the popular points of sale which are located in the district of the town Bratislava which is different from the place of residence is shown in Figure 4. 


\section{The customer segmentation}

When applying the two-step method which constructed two clusters we received a good quality of clustering (see Figure 5). The output of this phase of processing was a new variable showing the belonging to the given cluster.

Figure 5 | Cluster Quality by Silhouette Measure of Cohesion and Separation

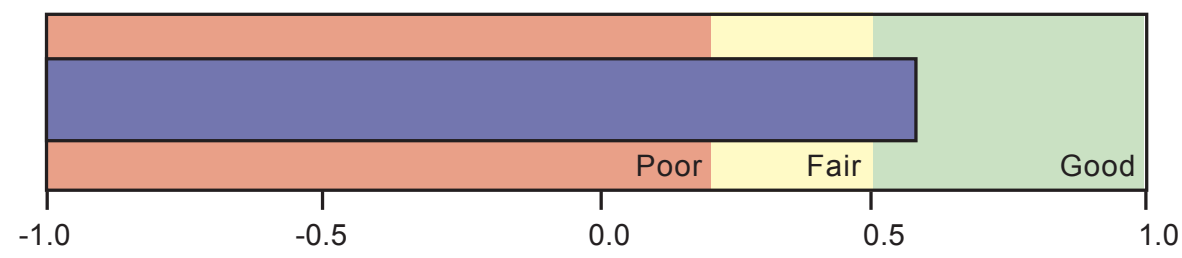

Source: own processing

Then we constructed two groups of decision trees created on the basis of two aspects, both groups being constructed by means of three selected methods (CART, QUEST CHAID). The variable being explained was always a newly constructed one showing the belonging to the cluster. When processing according to the first aspect, the explaining variables were the ones containing the identifying data (e.g. age, sex, income, number of family members, district), or in the case of the second aspect the variables representing the popularity of individual purchasing opportunities. In all cases we chose the tree with the best quality, i.e. the lowest value of risk estimate, which expressed the extent of badly classified cases. One tree of each group is depicted in the Figure 6 and Figure 7.

Risk estimate with all created trees in the second group ranged from 0.029 to 0.034 . It means the level of success of classing the objects ranged from $97.1 \%$ to $96.6 \%$. Then the quality of the second group of models was very high, from the qualitative aspect individual models are very comparable, all being very applicable to interpret the results. Risk estimate with all constructed trees in the first group of models ranged from 0.349 to 0.352 . It means that the level of success of grouping the objects ranged from $65.1 \%$ to $64.8 \%$. The quality of the models in the first group was not quite high but in spite of that the constructed models can be well applied. Individual models are again very comparable from the qualitative point of view and so they are well applicable to interpret the results.

On the basis of the structure of these selected trees we could describe the groups constructed by cluster analysis. This way we found out what type of respondents prefers a specific type of shopping.

All used algorithms in constructing decision trees on the basis of the first aspect showed postcode as an item which has the greatest influence on assigning to clusters. To avoid the opacity of outputs we excluded this item from processing and let the item district as the only one identifying the residence. Having done this the quality of models was not changed at all (only some tenths of per cent) which means that this act did not lead to making the final outputs worse and could be perfectly used. The task of the most influential item in these new models was taken by the item district. 


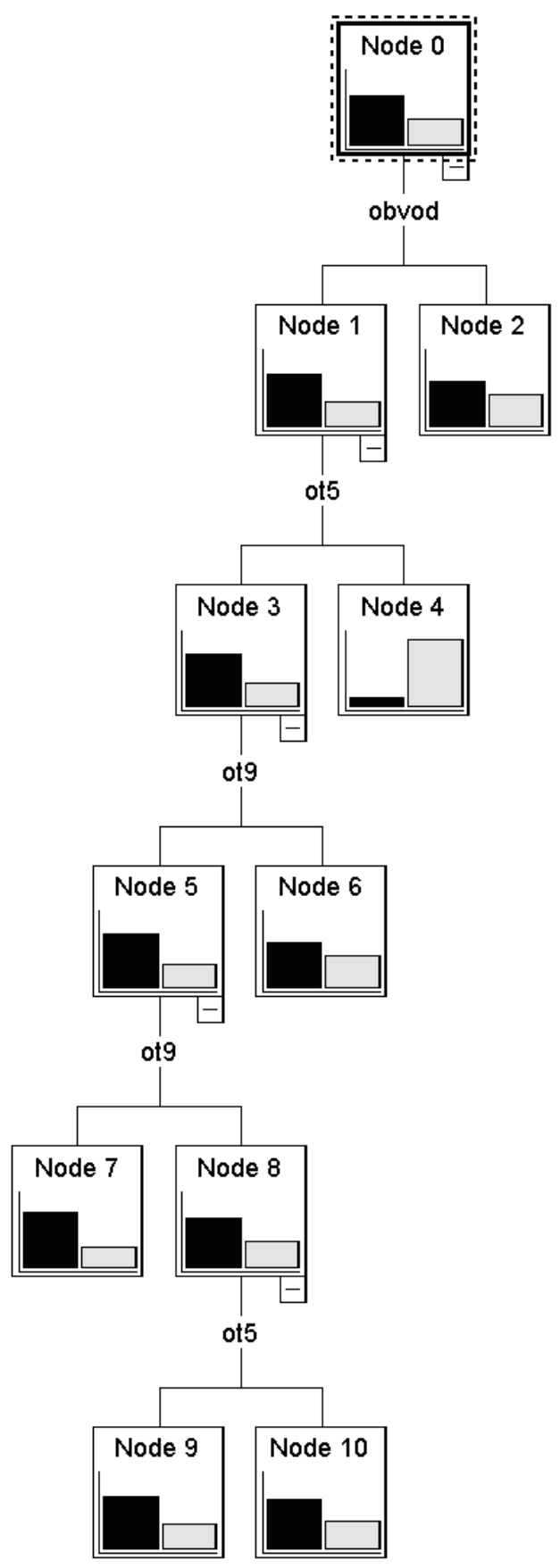

1.000

2.000

Source: own processing 


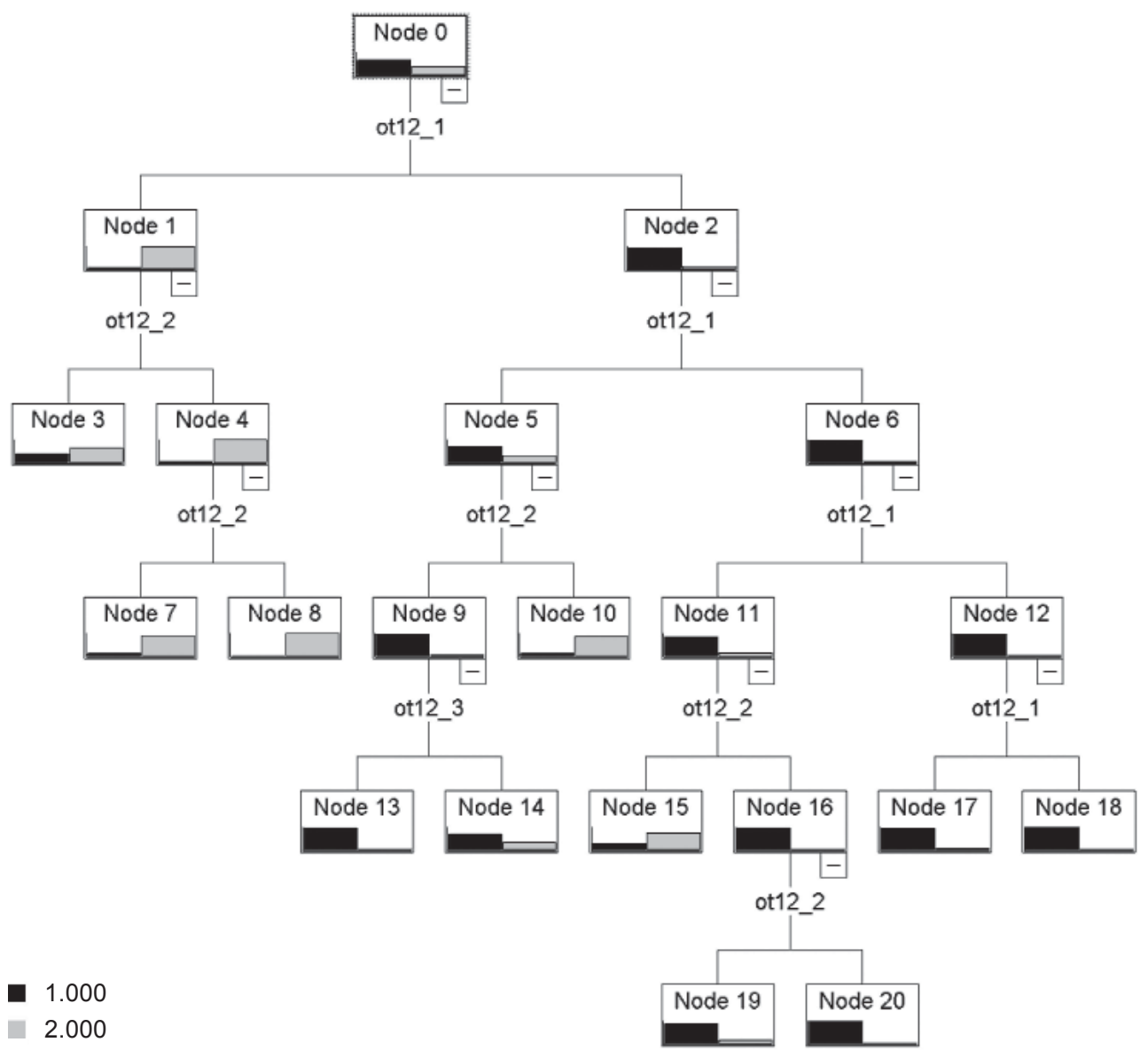

Source: own processing

The respondents of the districts 2 and 5 merged very closely and so did the respondents of the districts 1 and 3 being more loosely joined by the respondents of the district 4 . The second most influential item was the information on the number of family members, the third was the information on frequency and duration of shopping. Some models also revealed the influence of age and income of respondents. 


\begin{tabular}{|c|c|c|}
\hline \multicolumn{3}{|c|}{ Cluster A } \\
\hline Method & The first aspect & The second aspect \\
\hline QUEST & $\begin{array}{l}\text { The respondents of the } \\
\text { districts } 2 \text { and } 5 \text {, whose } \\
\text { households consist of } 2-3 \\
\text { members, who go shopping } \\
\text { regularly. }\end{array}$ & $\begin{array}{l}\text { - The respondents who prefer stores with electrical } \\
\text { ware, buffets, toy shops, and the butcher's, the } \\
\text { tobacconist's and markets. } \\
\text { - The respondents who are satisfied with the } \\
\text { approach of a shop assistant to the customer, } \\
\text { accessibility of the store, banking services, lack } \\
\text { of shop assistants, organization of the store and } \\
\text { who do not prefer the following types of retail } \\
\text { trade - the grocer's, stores with furnishings, } \\
\text { household utensils, sports ware, jeweller's, sex } \\
\text { shops. }\end{array}$ \\
\hline CRT & $\begin{array}{l}\text { The respondents of the } \\
\text { districts } 2 \text { and } 5 \text { (who did } \\
\text { not give the numbers of the } \\
\text { members of their families), } \\
\text { who go shopping several } \\
\text { times a week, their income } \\
\text { exceeds } 900 \text { euro and are } \\
\text { older than } 28.5 \text { years. } \\
\text { - The respondents of the } \\
\text { districts } 2 \text { and } 5 \text { who do very } \\
\text { little shopping, mostly on } \\
\text { Sundays or Mondays. }\end{array}$ & $\begin{array}{l}\text { - The respondents preferring shopping in the v Billa, } \\
\text { Carrefour, Jednota, Lidl, Metro, Albert due to } \\
\text { a better assortment, lower prices or due to their } \\
\text { being accustomed according to who there have } \\
\text { been no or only small changes in the quality } \\
\text { of shopping. } \\
\text { - The respondents who did not classify the closest } \\
\text { grocery shop with 1, and on the contrary they did } \\
\text { not classify other retail stores in their area with } 5 \text {. } \\
\text { The respondents who do not make more than } 2.5 \\
\text { hours on the way to the store and according to } \\
\text { who there have not been any or very small changes } \\
\text { in the quality of shopping. }\end{array}$ \\
\hline CHAID & $\begin{array}{l}\text { - The respondents of the } \\
\text { districts } 2 \text { and } 5 \text {, who go } \\
\text { shopping more times a week } \\
\text { and have a wide family. } \\
\text { - Young people to } 32 \text { years of } \\
\text { age of the } 1 \text { and } 3 \text { districts, } \\
\text { who do shopping for more } \\
\text { than } 175 \text { minutes. } \\
\text { - The respondents of the } \\
\text { district } 4 \text { who have a wide } \\
\text { family, who do shopping } \\
\text { mostly no longer than } 11 \\
\text { minutes. }\end{array}$ & $\begin{array}{l}\text { - The respondents shopping most often at the } \\
\text { chemist's, shoe shop, tobacconist's, stationer's, } \\
\text { baker's, who are missing some assortment in the } \\
\text { shops and who would like the quality of services to } \\
\text { be improved, who consider the time queuing to be } \\
\text { too long and who are missing the information on } \\
\text { products. } \\
\text { - The respondents who classify the accessibility } \\
\text { of the store with } 4 \text { and who do not drive to the } \\
\text { store and most often do shopping at the clothier's, } \\
\text { ironware shops, chemist's, computer shops and } \\
\text { shops with garden ware. } \\
\text { - The respondents who would appreciate longer } \\
\text { sales out, improvement of barrier-free access, } \\
\text { better facilities of stores or introduction of } \\
\text { children's corner. }\end{array}$ \\
\hline
\end{tabular}




\begin{tabular}{|c|c|c|}
\hline \multicolumn{3}{|c|}{ Cluster B } \\
\hline Method & The first aspect & The second aspect \\
\hline QUEST & $\begin{array}{l}\text { The respondents of the districts } 1,3 \\
\text { and } 4 \text {. } \\
\text { The respondents of the districts } \\
2 \text { and } 5 \text { who go shopping only } \\
\text { occasionally. }\end{array}$ & $\begin{array}{l}\text { The respondents most often shopping at the } \\
\text { stores with furnishings, the jeweller's, shops } \\
\text { with stockings or sex shops, who are often } \\
\text { missing discounts, children's corner and are } \\
\text { not satisfied with the accessibility of the store. }\end{array}$ \\
\hline CRT & $\begin{array}{l}\text { The respondents of the districts } \\
2 \text { and } 5 \text { who go shopping only } \\
\text { occasionally. } \\
\text { The respondents of the districts } 1 \text {, } \\
3 \text { and } 4 \text { who spend shopping } \\
\text { less than } 1.5 \text { hours, go shopping } \\
\text { on weekdays and their income } \\
\text { exceeds } 660 \text { euro and is smaller } \\
\text { than } 1,330 \text { euro. } \\
\text { The respondents of the districts } 1 \text {, } \\
3 \text { and } 4 \text { who are at least } 20 \text { years } \\
\text { old, do not buy on Fridays and } \\
\text { Saturdays and spend shopping } \\
\text { at least } 3 \text { hours. }\end{array}$ & $\begin{array}{l}\text { The respondents most often shopping at } \\
\text { the grocer's, shops with ironware, house } \\
\text { utensils, butcher's, cosmetics or tanking fuels, } \\
\text { preferring shopping at Billa, Carrefour, Lidl, } \\
\text { Tesco, Albert, Kaufland or Spare, who choose } \\
\text { the store because of a better assortment, } \\
\text { lower prices or are accustomed to it, who } \\
\text { do not think there have been a radical change } \\
\text { in their shop. } \\
\text { The respondents most often shopping at the } \\
\text { shops with electrical ware, furnishings, toys, } \\
\text { florist's or dispensing chemist's preferring } \\
\text { shopping at Billa, Hypernova, Jednota, HM, } \\
\text { who do not think there has been a radical } \\
\text { change of the situation in their store for the } \\
\text { worse. }\end{array}$ \\
\hline CHAID & $\begin{array}{l}\text { The respondents of the districts } \\
1 \text { and } 3 \text { who spend shopping } \\
\text { a quarter of an hour to } 2.5 \text { hours. } \\
\text { The respondents of the district } 4 \\
\text { who spend shopping a quarter } \\
\text { of an hour to } 1 \text { hour. }\end{array}$ & $\begin{array}{l}\text { The respondents most often shopping at } \\
\text { the grocer's, chemist's, shops with children's } \\
\text { clothes, cosmetics, the butcher's, baker's or } \\
\text { shops with mixed merchandise, who would } \\
\text { like the accessibility of the store, banking } \\
\text { services to be improved and the quantity } \\
\text { of healthy foodstuffs to be increased. }\end{array}$ \\
\hline
\end{tabular}

In the case of the second aspect the item of the highest importance for assigning to a cluster appeared to be the information on the choice of retail chain. From this aspect the respondents preferring famous chains were closely merged in contrast to the respondents preferring less known or small shops. The second place in the strength of influence was represented by the items containing information on the number and duration of shopping in other localities. From this aspect the respondents travelling to do shopping somewhere out regularly, minimum several times a week, were closely merged in contrast to the customers travelling to do shopping out only occasionally in a more than one week interval. From the interpretation aspect these items brought only little information and through their influence they overrode other items in the model. Therefore we tried to exclude them from further processing. The quality of models fortunately did not fall, therefore it was easily 
done. In the new constructed models the items with information on the type of the most often visited shops appeared to be important. There were three basic groups of respondents, namely the persons visiting mostly grocery stores, the butcher's, the baker's, the chemist's or the stores with children's clothes (supposing it concerns women - housewives), then there is a group of persons visiting mostly the stores specialised in electrical ware, computers, then the tobacconist's, sex shops or buffets. The last group from this aspect are the persons preferring visiting the stores selling furnishings, household utensils, sportswear or the jeweller's. The further items strongly influencing assigning to the clusters are also the items containing information on the reason of selection of the chain visited, on drawbacks which a respondent feels in his store or the information on the level of satisfaction with the store. The Table 2 summarizes these results clearly.

\section{Limits of research}

It may be asked why in this paper a Bratislava retail network in selected aspects of consumer behaviour was treated only. Population of Bratislava city is more than 500,000 habitants and it cannot compare its retail network and buying behaviour of habitants with other Slovakian cities which population is less than 100,000 habitants (Križan, Tolmáči, Lauko, 2008). The consumer behaviour of the Bratislava consumers might not be considered for a general model applied for whole Slovakia. Others aspects such as transport network, highways and geographic location, e.g. proximity to Vienna, Brno and Budapest are not comparable with another cities. According to international business research, some researchers identify retail-specific context in single cities, e.g. Clarke, G. et al. (2002) applied localisation of new stores on British cities or Sparks, A. L. et al. (2011 used GIS methods to construct measures of food access for neighbourhoods in the Portland, Oregon. Consequently, paper offers an overview of the most promising locations for new points of sales in the separate districts on the basis of characteristics of buying behaviour of the consumers.

\section{Conclusion}

Better knowledge of the space behaviour of a customer enables the distributer to understand the attractiveness of the sales point and plan the future implantation of a new point of sale in a given district. The constructed models resulted in the fact that the opinions and behaviour of customers are most influenced by the locality of their residence, size of their families and frequency and duration of their shopping, to a smaller extent also by age and income of a respondent.

We can see that the women-housewives with an average income, living in the districts 1 and 3, who do shopping mostly on weekdays and do not spend shopping more than 1.5 hours choose their store (mostly the grocer's, butcher's, baker's, shops with children's clothes, toyshops) on the basis of assortment, price level or only on the basis of a custom whilst they do not think that lately there have been any radical changes in the quality of shopping in their stores. They prefer shopping in famous retail chains. When shopping they would welcome improvement in the sphere of accessibility of the store, banking services and they would appreciate increase of the quantity of healthy and bio foodstuffs.

The respondents of the 2 and 5 districts shopping less often or occasionally, mostly at the stores with furnishings, household utensils, sportswear or at the jeweller's, in average spend shopping several hours. These respondents are not aware of any changes for the 
worse in the stores, but they are not satisfied with the accessibility of the stores, they are missing discounts and children's corner in the store.

Another group are the respondents of the districts 2 and 5 who do shopping very little, mostly on Sundays or Mondays, but also young people of the districts 1 and 3, who spend much time shopping (in average over 175 minutes). This group largely consists of customers shopping at the stores with electrical ware, computers, the tobacconist's, sex shops or buffets as well as of the respondents who are satisfied with their stores as far as the approach of shop assistants, organization of the store and banking services are concerned. They would welcome a longer time of discounts, improvement of facilities of stores and barrier-free access to the stores.

The residents of the districts 2 and 5 shopping more times a week whose income exceeds the average and who are older than 29 years, who buy most often at the butcher's, tobacconist's, shops with electrical ware, florist's or toy shops are not aware of more radical improvement in the quality of purchase, they are satisfied with their stores at an average rate.

The residents of the districts 2 and 5 who share the residence with maximum two more persons and go shopping in the area of their residence regularly, the customers who get to their stores travelling, most often do shopping at the baker's, chemist's, tobacconist's, stationer's or shoe shops, are not satisfied with the offered assortment, with a long time spent queueing, they would welcome the quality of services to be improved and they are missing sufficient information on the offered products.

In addition further research can benefit from this paper considered for a part in timeline survey of development of the retail network and the consumer behaviour in building the time-space model of consumer behaviour for citizens of Bratislava.

\section{References}

Boučková, J. et al. (2007). Základy marketingu. Prague: Nakladatelství Oeconomica, VŠE. ISBN 978-80-245-1169-6.

Brida, J. G. et al. (2014). Segmenting Cruise Passengers Visiting Uruguay: A Factor-Cluster Analysis. International Journal of Tourism Research, 16(3), 209-222. DOI: 10.1002/jtr.1916.

Corodescu, E. (2014). GIS Approach in Assessing the Rural Space Accessibility - Case Study: Vaslui County, Romania. Geographia Technica, 9(1), 20-30.

Clarke, G., Eyre, H., Guy, C. (2002). Deriving Indicators of Access to Food Retail Provision in British Cities: Studies of Cardiff, Leeds and Bradford. Urban Studies, 39(11), 2041-2060.

DOI: 10.1080/0042098022000011353.

Douard, J., Heitz, P. M. (2004). Le géomarketing. Paris: Dunod. ISBN 978-21-0006-906-4.

Drezner, T. (1994). Optimal Continuous Location of a Retail Facility, Facility Attractiveness, and Market Share: An Interactive Model. Journal of Retailing, 70(1), 49-64.

DOI: 10.1016/0022-4359(94)90028-0.

Kita, J. Konštiak, P. (2012). Space Aspects of Relationship of Habitants in Territory Geomarketing. Bratislava: Vydavatelštvo Ekonóm.

Križan, F., Tolmáči, L., Lauko, V. (2008). Identification of "Food Deserts" in the City of Bratislava by Application Accessibility Measures. Journal of Economics, 56(10), 959-972.

Križan, F., Bilková, K., Zubriczký, G., Riška, M., Barlík, P. (2014). Identification and Mapping of Food Deserts in Rural Areas: A Case Study from Slovakia. Geographia Technica, 9(2), 54-59. 
McDonald, M., Dunbar, I. (2000). Market Segmentation: How to Do lt, How to Profit from It. Elsevier Butterworth-Heinemann Oxford.

Roy, J. R., Thill, J. C. (2004). Spatial Interaction Modeling. Papers in Regional Science, 83(4), 339-361.

Řezanková, H., Húsek, D., Snášel, V. (2009). Shluková analýza dat. 2nd Ed. Prague: Professional Publishing. ISBN 978-80-86946-81-8.

Sparks, A. L., Bania, N., Leete, L. (2011). Comparative Approaches to Measuring Food Access in Urban Areas: The Case of Portland, Oregon. Urban Studies, 48(8), 1715-1737.

DOI: $10.1177 / 0042098010375994$.

Suárez-Vega, R., Santos-Peñate, D. R., Dorta-González, P., Rodríguez-Díaz, M. (2011). A MultiCriteria GIS Based Procedure to Solve a Network Competitive Location Problem. Applied Geography, 31(1), 282-291. DOI: 10.1016/j.apgeog.2010.06.002.

Šveda, M., Križan, F. (2012). The Manifestation of Commercial Suburbanization in the Selected Sectors of Economy in the Hinterland of Bratislava. Journal of Economics, 60(5), 460-481.

Thang, D. C. L., Tan, B. L. B. (2003). Linking Consumer Perception to Preference of Retail Stores: An Empirical Assessment of the Multi-Attributes of Store Image. Journal of Retailing and Consumer Services, 10(4), 193-200. DOI: 10.1016/S0969-6989(02)00006-1.

Tsai, C., Chiu, C. (2004). A Purchase-Based Market Segmentation Methodology. Expert Systems with Applications, 27(2), 265-276. DOI: 10.1016/j.eswa.2004.02.005.

Turhan, G., Akalin, M., Zehir, C. (2013). Literature Review on Selection Criteria of Store Location Based on Performance Measures. Social and Behavioural Sciences, 99(6), 391-402.

DOI: 10.1016/j.sbspro.2013.10.507.

ONLINE FIRST PRAGUE ECONOMIC PAPERS 15

Vojáček, O. (2011). Preference Dilemma in Economics. Politická ekonomie, 59(3), 345-358.

DOI: 10.18267/j.polek.795.

Więckowski, M., Michniak, D. (2012). Možnosti zlepšenia dostupnosti a rozvoja cestovného ruchu v Pol'sko-Slovenskom pohraničí. Bratislava: Geografi ckýústav SAV.

Wooda, S., Reynolds, J. (2012). Leveraging Locational Insights within Retail Store Development? Assessing the Use of Location Planners' Knowledge in Retail Marketing. Geoforum, 43(6), 1076-1087. DOI: 10.1016/j.geoforum.2012.06.014.

Williams, H. C. W. L., Kim, K. S. (1990). Location-Spatial Interaction Models: 2 Competition between Independent firms. Environment and Planning A, 22(9), 1155-1168.

DOI: $10.1068 / a 221155$.

Žambochová, M. (2008). Jak na rozhodovací stromy. Informační Bulletin, 19(3), 1-12.

Žambochová, M. (2012). Typology of Foreign Students Interested in Studying at Czech Universities. E+M - Ekonomika a Management, 15(2), 141-153. 